\title{
MALTING BARLEY DISEASES, YIELD AND QUALITY - RESPONSES TO USING VARIOUS AGRO-TECHNOLOGY REGIMES
}

\author{
Tiia Kangor", Pille Sooväli, Ylle Tamm, IImar Tamm, and Mati Koppel \\ Estonian Crop Research Institute, Aamisepa 1, Jõgeva, EE-48309, ESTONIA \\ pille.soovali@etki.ee, ylle.tamm@etki.ee, ilmar.tamm@etki.ee, mati.koppel@etki.ee \\ \# Corresponding author: tiia.kangor@etki.ee
}

Communicated by Zinta Gaile

\begin{abstract}
Pyrenophora teres (net blotch) and Cochliobolus sativus (spot blotch), the most widely spread diseases in the Northern Baltic region, have high impact on cereal production. The effect of three levels of fertilisation and two fungicide treatments on the severity of barley diseases, grain yield and quality traits (protein content, test weight, thousand kernel weight (TKW), grading) was tested during a period of three years. Weather conditions during the growing season highly determined disease severity, yield and quality. In addition, the infection level of $\mathrm{P}$. teres was more dependent on fungicide treatment $(\mathrm{p} \leq 0.001)$ and barley variety $(\mathrm{p} \leq 0.001)$ while $\mathrm{C}$. sativus infection was influenced more by fertilisation ( $\mathrm{p} \leq 0.001)$ and year $x$ fertilisation interaction $(\mathrm{p} \leq 0.001)$. Fungicide treatment had no influence on grain yield and protein content, but slightly improved TKW ( $\mathrm{p} \leq$ $0.05)$, test weight $(\mathrm{p} \leq 0.001)$ and grading $(\mathrm{p} \leq 0.001)$. However, these quality traits were mostly influenced by barley variety ( $\mathrm{p} \leq 0.001)$. TKW and test weight were highest at fertilisation level $\mathrm{N}_{80} P_{12} K_{43}$. The effect of year and fertilisation contributed significantly to the grain protein content. Grain yield and protein content were highest at the maximum fertiliser application $\left(N_{100} P_{15} K_{54}\right)$.
\end{abstract}

Key words: malting barley, yield, quality, disease severity, fertilisation.

\section{INTRODUCTION}

For barley, major changes in crop protection schemes are expected in the Baltic region due to northward spread of new pests and higher infestation pressure from native diseases due to higher precipitation (Olesen et al., 2011). This has raised questions about the role of optimising fertiliser and fungicide application to improve malting barley yield and grain quality. The influence of fertiliser and fungicide application on modern barley varieties has earlier been studied in various climatic regions including Canada (O'Donovan et al., 2011) and Scotland (Bingham et al., 2014), but not sufficiently in the Northern Baltic region. Improving the efficiency of fertiliser and fungicide application requires better understanding of the effect of fertilisation and fungicide treatment regimes on malting barley yield and quality.

Malting barley has to meet certain specific quality requirements set by the malt industry. Recent breeding programmes have released modern malting barley varieties that meet the required standards of protein content, thousand kernel weight (TKW), grading, test weight and disease resistance (Leistrumaite et al., 2008). The most critical characteristic is grain protein content, which should be in the range of $9.0-11.5 \%$. Previous research has shown that pro- tein content is more influenced by the agro-technology used and growing conditions than by varieties (Schwarz and Horsley, 1996; Oscarsson et al., 1998). However, certain varieties are able to better maintain protein content within the required range under fluctuating growing conditions (Briggs, 1998; Savin and Molina-Cano, 2002). According to the standard set by malt industry and purchasing companies, barley grain should have a test weight over $640 \mathrm{~g} \cdot \mathrm{L}^{-1}$, TKW of at least $41.0 \mathrm{~g}$ and grading $(>2.5 \mathrm{~mm}$, kernels above 2.5 $\mathrm{mm}$ sieve) at least $90 \%$.

Barley yield, kernel weight and protein content are higher with increasing rates of fertilisation (Spaner et al., 2001; O'Donovan et al., 2011; Turkington et al., 2012). High rates of fertilisers, mainly nitrogen, have been shown to increase grain yield, but can stimulate spread of foliar diseases (Olesen et al., 2003). Net blotch caused by Pyrenophora teres and spot blotch caused by Cochliobolus sativus are the most prevalent barley leaf diseases in Estonia (Sooväli and Koppel, 2010). Infection from net and spot blotch occurs every year, whereas other barley diseases known from the region are much less common and their impact on grain yield and quality is relatively small. In the case of severe epidemic outbreaks, net blotch can cause sig- 
nificant reduction in grain yield (Khan, 1987; Jayasena et al., 2002) and quality characteristics leading to overall downgrading of grain quality (Vanova et al., 2006; Cooper et al., 2007). In general, infection of the upper two leaves is sufficient to cause reductions in yield and grain quality through reduced grain size. Fungicides reduce the level of infection and therefore increase grain yield when the risk of disease is severe (Yang et al., 2000; Vanova et al., 2006). Previous research indicates that fungicide application during the flag leaf emergence (BBCH 39) (Meier, 2001) until head emergence growth stage (BBCH 59) will provide more benefit than when applied during earlier growth stages (BBCH 20-29) (Turkington et al., 2004).

The aim of the present study was to determine the effect of fertiliser and fungicide application on modern malting barley varieties in order to improve yield and grain quality under the climatic conditions of the Northern Baltic region.

\section{MATERIALS AND METHODS}

Field experiments. Field experiments were carried out at the Estonian Crop Research Institute (ECRI) in Jõgeva (58 44'41" N, 26²3'41" E) during 2011-2013. Soil type at the experimental site was Cambisol with sandy loam texture $\left(\mathrm{pH}_{\mathrm{KCl}}\right.$ 5.6-5.9; concentration of soil organic $\mathrm{C} 1.8-2.0 \%$; available P $165-238 \mathrm{mg} \cdot \mathrm{kg}^{-1}, \mathrm{~K} 179-298 \mathrm{mg} \cdot \mathrm{kg}^{-1}$ and $\mathrm{Ca}$ 1389-1589 $\mathrm{mg} \cdot \mathrm{kg}^{-1}$ ). Field trials were set up as a multifactorial experiment with three replicates in a randomised complete block design in $5 \mathrm{~m}^{2}$ plots at the rate of 500 viable seeds per $1 \mathrm{~m}^{2}$. Four two-row malting barley varieties were used: 'Grace' (Germany) and 'Quench' (UK), which were moderately resistant to net and spot blotch, and 'Posada' (Germany) and 'Propino' (UK), which were moderately susceptible to net and spot blotch. The varieties were selected based on data from previous disease scoring trials at the ECRI and interest in these varieties by farmers. 'Grace', 'Propino' and 'Quench' are the most commonly grown malting barley varieties in Sweden and Lithuania (Anonymous, 2015). The experimental fields were ploughed in autumn and pre-crops were potato $(2011,2013)$ and spring oilseed rape (2012). Seed treatment was Maxim Star 025FS (fludioxonil $18.8 \mathrm{~g} \cdot \mathrm{L}^{-1}$ cyproconazole $6.3 \mathrm{~g} \cdot \mathrm{L}^{-1}$ ) $1.5 \mathrm{~L} \cdot \mathrm{t}^{-1}$. All trials were sown at the optimal time in the first week of May. Three levels of complex fertiliser, labelled as Arvi NP-K: 17-6-11 (Lithuania, $\mathrm{P}$ and $\mathrm{K}$ were shown as oxides), were used before sowing: $\mathrm{N} 1-\mathrm{N}_{60} \mathrm{P}_{9} \mathrm{~K}_{32}$ (as pure elements), $\mathrm{N} 2-\mathrm{N}_{80} \mathrm{P}_{12} \mathrm{~K}_{43}, \mathrm{~N} 3-\mathrm{N}_{100} \mathrm{P}_{15} \mathrm{~K}_{54}$. Two fungicide regimes were used: $\mathrm{T} 1-$ Artea $\left(80 \mathrm{~g} \cdot \mathrm{L}^{-1}\right.$ cyproconazole, $250 \mathrm{~g} \cdot \mathrm{L}^{-1}$ propiconazole) $0.4 \mathrm{~L} \cdot \mathrm{ha}^{-1}$ at booting stages (BBCH 40-49), T2 - Artea $0.2 \mathrm{~L} \cdot \mathrm{ha}^{-1}$ at shooting stages (BBCH 32-35) and Zantara (50 g. $\mathrm{L}^{-1}$ bixafen, $166 \mathrm{~g} \cdot \mathrm{L}^{-1}$ tebuconazole) $0.6 \mathrm{~L} \cdot \mathrm{ha}^{-1}$ at heading to flowering stages (BBCH 55-65). Fungicides were applied with a bicycle sprayer equipped with six Hardy nozzles $4110-12$ on a 2.5 $\mathrm{m}$ boom using $300 \mathrm{~L}$ water per ha ${ }^{-1}$. Untreated plots were used as a control. Recommended weed and insect control practices were applied uniformly across the field as needed.
Trials were harvested with a plot combine harvester in mid of August at fully ripe stage (BBCH 89).

Field observations. Phenological growth stages were determined according to $\mathrm{BBCH}$-identification keys for cereals when $>50 \%$ of the plants had reached the target growth stage. Disease severity was scored as the percent of leaf area infected by $P$. teres and $C$. sativus at milk growth stages (BBCH 71-75). We merged the observations of net blotch net type caused by $P$. teres $f$. teres and net blotch spot type caused by $P$. teres $f$. maculate. Disease severity was evaluated on the two upper leaves on three adjacent tillers at five randomly selected sites on each plot (30 leaves on 15 tillers in total per plot) and the disease severity was expressed as an average of the infection score per plot.

Sampling and grain quality analysis. Grain yield $\left(\mathrm{kg} \cdot \mathrm{ha}^{-1}\right)$ and grain quality characteristics, such as thousand kernel weight (TKW; g), were measured by ISTA method. Test weight (TW; g. $\mathrm{L}^{-1}$ ) was measured by an automatic grain analyser Infratec ${ }^{\mathrm{TM}} 1241$ (Foss, Cheshire, UK), protein content (PC; \%) by near-infrared method using a XDS Rapid Content Analyser (Foss, Cheshire, UK) and grading (MG; \%) (percentage of plump kernels above $2.5 \mathrm{~mm}$ sieve) by Sortimat equipment (Falling Number, Sweden). In order to measure the grading, the kernels were sieved using mesh sizes of $2.2 \mathrm{~mm}, 2.5 \mathrm{~mm}$ and $2.8 \mathrm{~mm}$. Qualitative and quantitative analysis of the yield parameters were conducted on dried and cleaned grain and expressed on the basis of $14 \%$ moisture content.

Statistical analysis. All data were analysed with software package Agrobase 20 using the combined analysis of variance (combined RCBD ANOVA). Combined analysis of variance was performed to determine the main factors and their interactions. Omega square $\left(\omega^{2}\right)$ was calculated to determine relative impact of each single factor in variation of yield, grain quality and disease severity (Grissom and Kim, 2012). Mean separations were made for significant effects with LSD at probability $p \leq 0.05$. The significance of effect of factors was determined at probability levels of $p \leq 0.05$; $p \leq 0.01 ; p \leq 0.001$.

Meteorological data. Weather data were obtained from the field meteorological weather station Metos Compact (Pessl Instruments $\mathrm{GmbH}$, Austria) located in Jõgeva, close to the trial site. 2011 was characterised by warm and dry weather, there were some periods of drought observed during May to July (Table 1). The average temperature was higher and precipitation occurred less, than the long-term average. These growing conditions inhibited barley tillering, particularly the number of grain-producing ears per plant (data not shown). Drought conditions at the end of tillering and beginning of stem elongation $(\mathrm{BBCH} 29-30)$ reduced grain yield and quality. The same conditions prevailed beforeand post-ear emergence and grain filling stages $(\mathrm{BBCH}$ 31-71). The year 2012 was characterised by similar temperature as the long-term average and there was more precipitation than the long-term average. Cool and wet conditions during before mentioned growth stages of barley 
AVERAGE TEMPERATURES AND SUMS OF PRECIPITATION IN THE VEGETATION PERIOD IN JÕGEVA, 2011-2013

\begin{tabular}{|c|c|c|c|c|c|c|c|c|}
\hline \multirow[t]{2}{*}{ Month } & \multicolumn{3}{|c|}{ Average temperature ${ }^{\circ} \mathrm{C}$} & \multirow{2}{*}{$\begin{array}{c}\text { Long-term } \\
\text { average }{ }^{*}{ }^{\circ} \mathrm{C}\end{array}$} & \multicolumn{3}{|c|}{ Sum of precipitation, $\mathrm{mm}$} & \multirow{2}{*}{$\begin{array}{c}\text { Long-term } \\
\text { average* mm }\end{array}$} \\
\hline & 2011 & 2012 & 2013 & & 2011 & 2012 & 2013 & \\
\hline May & 11.0 & 11.5 & 14.3 & 10.2 & 34 & 62 & 83 & 49 \\
\hline July & 20.5 & 17.9 & 17.6 & 16.8 & 34 & 85 & 35 & 80 \\
\hline August & 16.3 & 14.7 & 16.7 & 15.3 & 74 & 130 & 70 & 89 \\
\hline May-August & 16.3 & 14.4 & 16.6 & 14.2 & 180 & 387 & 225 & 286 \\
\hline
\end{tabular}

* mean temperature and precipitation based on data from 1922-2012 (Jõgeva)

resulted in high yield, low protein content and high TKW. The growing season of 2013 was warm and dry and characterised by the sum of precipitation in June and July below the long-term average. The year 2013 was dray and hot during filling period, similar as in 2011, but the influence of these conditions on grain yield and quality was not so drastic as in 2011. The infection of spot blotch was slight in 2011, while infection of net blotch remained slight in 2012. Net and spot blotch infections were more severe in 2013.

\section{RESULTS}

Disease severity and grain yield. Infection by net blotch was more severe than by spot blotch during all trial years and in all tested barley varieties (Table 2). The impact of the year (the weather and soil conditions in the individual season) had the biggest influence on the disease severity of both diseases (Table 3). Fertilisation was another important factor influencing the severity of both diseases. The most important interaction determining the severity of spot blotch was between year and fertiliser. Fungicide treatment reduced disease severity of net blotch more effectively than of spot blotch.

Very low infection by spot blotch occurred in 2011. Infection by both diseases was more severe in 2013 and the infection levels were significantly higher in N3. T2 fungicide application (BBCH 32-35 and 55-65) resulted in significantly better disease control compared with treatment $\mathrm{T} 1$ (BBCH 40-49). There were no significant differences in disease severity of spot blotch between untreated and T1.

Variety 'Grace' had significantly lower infection by net blotch compared to other varieties. The net blotch infection reached the highest level in 'Posada' in 2013. Across the years, significantly lower infection by spot blotch occurred on varieties 'Grace' and 'Posada' than 'Quench' and 'Propino'.

It was confirmed that grain yield was determined by yearly climatic conditions, fertiliser treatment, variety and some interactions, but there was no significant effect of fungicide application on grain yield. Grain yield differed significantly between years and best average yield occurred in 2012. Fertilisation treatments $\mathrm{N} 1$ to $\mathrm{N} 3$ caused significant effect on yield, being significantly lower in the case of N1. There
Table 2

AVERAGE BARLEY DISEASE SEVERITY AND GRAIN YIELD IN RESPONSE TO YEAR, FERTILIZER INPUT, FUNGICIDE TREATMENT AND VARIETY IN JÕGEVA

\begin{tabular}{lcccc}
\hline \multicolumn{1}{c}{ Factor } & Spot blotch \% & Net blotch \% & $\begin{array}{c}\text { Grain yield } \\
\mathrm{kg} \cdot \mathrm{ha}^{-1}\end{array}$ \\
\hline Year & & & \\
2011 & $3.8 \mathrm{c}$ & $16.0 \mathrm{~b}$ & $5360 \mathrm{c}$ \\
2012 & $7.9 \mathrm{~b}$ & $12.9 \mathrm{c}$ & $7320 \mathrm{a}$ \\
2013 & $12.6 \mathrm{a}$ & $22.4 \mathrm{a}$ & $5640 \mathrm{~b}$ \\
\hline Fertilization & & & \\
N1 & $7.6 \mathrm{~b}$ & $16.1 \mathrm{~b}$ & $5660 \mathrm{c}$ \\
N2 & $6.9 \mathrm{c}$ & $16.1 \mathrm{~b}$ & $6190 \mathrm{~b}$ \\
N3 & $9.6 \mathrm{a}$ & $19.1 \mathrm{a}$ & $6470 \mathrm{a}$ \\
\hline Fungicide & & & $6030 \mathrm{a}$ \\
Untreated & $8.6 \mathrm{a}$ & $19.9 \mathrm{a}$ & $6120 \mathrm{a}$ \\
T1 & $8.2 \mathrm{a}$ & $18.1 \mathrm{~b}$ & $6160 \mathrm{a}$ \\
T2 & $7.5 \mathrm{~b}$ & $13.4 \mathrm{c}$ & \\
Variety & & & $6180 \mathrm{a}$ \\
Grace & $7.3 \mathrm{~b}$ & $13.4 \mathrm{~b}$ & $5900 \mathrm{~b}$ \\
Posada & $7.4 \mathrm{~b}$ & $18.9 \mathrm{a}$ & $6140 \mathrm{a}$ \\
Propino & $8.5 \mathrm{a}$ & $18.4 \mathrm{a}$ & \\
Quench & $9.0 \mathrm{a}$ & $17.8 \mathrm{a}$ &
\end{tabular}

$\mathrm{N} 1-\mathrm{N}_{60} \mathrm{P}_{9} \mathrm{~K}_{32} ; \mathrm{N} 2-\mathrm{N}_{80} \mathrm{P}_{12} \mathrm{~K}_{43} ; \mathrm{N} 3-\mathrm{N}_{100} \mathrm{P}_{15} \mathrm{~K}_{54}$ (as pure elements)

T1 - single application per season (BBCH 40-49); T2 - two applications per season (BBCH 32-35; BBCH 55-65)

Different letters mean significant differences within the factor at $p \leq 0.05$

Table 3

THE EFFECT SIZE OF FACTORS $\left(\omega^{2}\right)$ ON VARIATION OF SPOT BLOTCH, NET BLOTCH AND GRAIN YIELD

\begin{tabular}{|c|c|c|c|}
\hline Source of variation & Spot blotch & Net blotch & Yield \\
\hline Year & $0.54 * * *$ & $0.26 * * *$ & $0.63 * * *$ \\
\hline Fertilization (Fert) & $0.05^{* * *} *$ & $0.03 * * *$ & $0.09 * * *$ \\
\hline Fungicide (Fung) & $0.01 *$ & $0.12 * * *$ & $0.00^{\mathrm{ns}}$ \\
\hline Variety & $0.02 * *$ & $0.08 * * *$ & $0.01 * * *$ \\
\hline Year $\times$ Fert & $0.03^{* * *}$ & $0.01^{\mathrm{ns}}$ & $0.03 * * *$ \\
\hline Year $\times$ Fung & $0.02 * * *$ & $0.03 * * *$ & $0.00^{\mathrm{ns}}$ \\
\hline Year $\times$ Variety & $0.02 * *$ & $0.06 * * *$ & $0.01 * * *$ \\
\hline
\end{tabular}

Significant at $* p \leq 0.05 ; * * p \leq 0.01 ; * * * p \leq 0.001$; ns, non-significant

Non-significant interactions are not shown 
were no significant differences between the grain yield of varieties except 'Posada', which had the lowest overall grain yield.

Grain quality. Our results showed that year had significant effect on grain quality; the largest effects were on protein content and grading (Table 4). Variety and year were major factors determining the TKW and TW. On the other hand, fertilisation and fungicide treatments had mostly significant, but marginal effect on the tested grain quality parameters. Grain quality was significantly determined by year $\mathrm{x}$ fertilisation and year $\mathrm{x}$ variety interactions.

Grain protein content was highest in 2011 and lowest in 2012 when levels were below the acceptable range for malting (Table 5). Protein content was significantly influenced by fertiliser treatment and was highest at the $\mathrm{N} 3$ rate. There were no significant differences in protein content among fungicide treatments as well as among tested varieties.

TW varied significantly between years, being highest in 2011. Fertilisation and fungicide treatments had few significant but marginal effects on TW. The tested varieties differed significantly in TW between varieties with 'Grace' having the highest level of TW.

TKW was lowest in 2011 and did not significantly differ between 2012 and 2013. TKW varied significantly due to fertilisation and fungicide treatments, however, the differences were small. 'Propino' had highest TKW and was more stable over the years, whereas 'Quench' had the lowest levels of TKW.

Grading was considerably lower in 2011 compared to the other two trial years. Grading differed moderately among fertilisation levels and fungicide treatments, being highest at lowest levels of fertiliser application (N1) and high level of fungicide application (T2). All tested varieties differed significantly in grading, with 'Propino' resulting in highest grading compared to others.

\section{DISCUSSION}

Results of this study indicate the importance of optimising fertiliser and fungicide applications in order to increase grain quality and yield of modern malting barley varieties in the Northern Baltic region. Optimum soil fertility ensures vigorous crop growth, which will likely improve tolerance to various diseases (Turkington et al., 2011). Our results confirm the findings of Yang et al. (2000), who showed that barley disease severity correlates highly with yearly climatic conditions. Multiyear trials in Finland have demonstrated that cereal leaf blotch disease severity increased over the last 40 decades (Jalli et al., 2011). Our results indicated that net blotch infection severity was greatest at highest fertiliser level $\left(\mathrm{N}_{100} \mathrm{P}_{15} \mathrm{~K}_{54}\right)$. Net blotch infection severity has been shown to depend also on growth stages and duration of high humidity periods (Deacon, 2006; Bleidere et al., 2012). It has been found in the UK that fungicide treatment
Table 4

THE EFFECT SIZE OF FACTORS $\left(\omega^{2}\right)$ ON VARIATION OF GRAIN QUALITY

\begin{tabular}{l|c|c|c|c}
\hline $\begin{array}{c}\text { Source of } \\
\text { variation }\end{array}$ & Protein \% & $\begin{array}{c}\text { Test weight } \\
\mathrm{g} \cdot \mathrm{L}^{-1}\end{array}$ & $\begin{array}{c}1000 \text { kernel } \\
\text { weight g }\end{array}$ & Grading \% \\
\hline Year & $0.72 * * *$ & $0.34 * * *$ & $0.33 * * *$ & $0.42 * * *$ \\
Fertilization (Fert) & $0.06 * * *$ & $0.01 *$ & $0.02 * * *$ & $0.02 * * *$ \\
Fungicide (Fung) & $0.00^{\mathrm{ns}}$ & $0.01 *$ & $0.03 * * *$ & $0.03 * * *$ \\
Variety & $0.01 * *$ & $0.29 * * *$ & $0.37 * * *$ & $0.28 * * *$ \\
Year $\times$ Fert & $0.02 * * *$ & $0.07 * * *$ & $0.03 * * *$ & $0.02 * * *$ \\
Year $\times$ Fung & $0.01 * *$ & $0.00^{\mathrm{ns}}$ & $0.00^{\mathrm{ns}}$ & $0.01 * * *$ \\
Year $\times$ Variety & $0.01 * *$ & $0.08 * * *$ & $0.04 * * *$ & $0.10 * * *$
\end{tabular}

Significant at $* p \leq 0.05 ; * * p \leq 0.01 ; * * * p \leq 0.001$; ns, non-significant

Non-significant interactions are not shown

Grading, \% of kernels above $2.5 \mathrm{~mm}$ sieve

T a ble 5

AVERAGE GRAIN QUALITY CHARACTERISTICS OF BARLEY IN RESPONSE TO YEAR, FERTILIZER INPUT, FUNGICIDE TREATMENT AND VARIETY IN JÕGEVA

\begin{tabular}{|c|c|c|c|c|}
\hline Factor & Protein \% & $\begin{array}{c}\text { Test weight } \\
\mathrm{g} \cdot \mathrm{L}^{-1}\end{array}$ & $\begin{array}{c}1000 \text { kernel } \\
\text { weight g }\end{array}$ & Grading \% \\
\hline \multicolumn{5}{|l|}{ Year } \\
\hline 2011 & $11.1 \mathrm{a}$ & $682 \mathrm{a}$ & $48.9 \mathrm{~b}$ & $87.7 \mathrm{c}$ \\
\hline 2012 & $8.8 \mathrm{c}$ & $669 \mathrm{~b}$ & $52.7 \mathrm{a}$ & $95.4 \mathrm{a}$ \\
\hline 2013 & $10.4 \mathrm{~b}$ & $656 \mathrm{c}$ & $52.7 \mathrm{a}$ & $94.1 \mathrm{~b}$ \\
\hline \multicolumn{5}{|l|}{ Fertilisation } \\
\hline N1 & $9.7 \mathrm{c}$ & $668 \mathrm{~b}$ & $50.8 \mathrm{c}$ & $93.1 \mathrm{a}$ \\
\hline $\mathrm{N} 2$ & $10.1 \mathrm{~b}$ & $670 \mathrm{a}$ & $52.0 \mathrm{a}$ & $92.7 \mathrm{~b}$ \\
\hline N3 & $10.4 \mathrm{a}$ & $668 \mathrm{~b}$ & $51.4 \mathrm{~b}$ & $91.4 \mathrm{c}$ \\
\hline \multicolumn{5}{|l|}{ Fungicide } \\
\hline Untreated & $10.0 \mathrm{a}$ & $666 \mathrm{~b}$ & $50.7 \mathrm{c}$ & $91.3 \mathrm{c}$ \\
\hline $\mathrm{T} 1$ & $10.1 \mathrm{a}$ & $670 a$ & $51.4 \mathrm{~b}$ & $92.3 \mathrm{~b}$ \\
\hline $\mathrm{T} 2$ & $10.1 \mathrm{a}$ & $669 \mathrm{a}$ & $52.1 \mathrm{a}$ & $93.6 \mathrm{a}$ \\
\hline \multicolumn{5}{|l|}{ Variety } \\
\hline Grace & $10.2 \mathrm{a}$ & $681 \mathrm{a}$ & $50.5 \mathrm{c}$ & $91.0 \mathrm{c}$ \\
\hline Posada & $10.0 \mathrm{~b}$ & $661 \mathrm{c}$ & $51.0 \mathrm{~b}$ & $89.8 \mathrm{~d}$ \\
\hline Propino & $10.1 \mathrm{ab}$ & $658 \mathrm{~d}$ & $54.6 \mathrm{a}$ & $97.0 \mathrm{a}$ \\
\hline Quench & $10.1 \mathrm{ab}$ & $676 \mathrm{~b}$ & $49.5 \mathrm{~d}$ & $91.8 \mathrm{~b}$ \\
\hline
\end{tabular}

$\mathrm{N} 1-\mathrm{N}_{60} \mathrm{P}_{9} \mathrm{~K}_{32} ; \mathrm{N} 2-\mathrm{N}_{80} \mathrm{P}_{12} \mathrm{~K}_{43} ; \mathrm{N} 3-\mathrm{N}_{100} \mathrm{P}_{15} \mathrm{~K}_{54}$ (as pure elements)

T1 - single application per season (BBCH 40-49); T2 - two applications per season (BBCH 32-35; BBCH 55-65)

Different letters mean significant differences $(p \leq 0.05)$ within the factor

Grading, \% of kernels above $2.5 \mathrm{~mm}$ sieve

is effective when the infection severity is more than $5 \%$ of leaf area (Cook et al., 1999), thus indicating that in the case of low-intensity infection fungicide treatment should be lowered or might not be necessary at all. According to Cooper et al. (2007), balanced and adequate soil fertility interacts with crop protection. Surplus of nutrients in the rhizosphere may aid foliar pathogen survival in soil and may cause foliar disease outbreaks. This was also evident from 
our study, where higher fertiliser treatment caused increased infection of spot and net blotch of barley plants. Disease severity is generally known to be influenced by the climatic conditions prevailing in a given year, being especially promoted by a combination of high precipitation and air temperature. Although we observed significant differences in disease severity of spot and net blotch between years, these could not be explained by differences in precipitation and temperature. Although we found that blotch infection was lowest in 2011 and highest in 2013, those years were both characterised by lower than average amount of precipitation. However, it could be assumed that the differences in blotch disease severity were caused by differences in air humidity during 2011 and 2013, although we lack direct measurements of that factor. Indeed, Duveiller and Altamirano (2000) found that spot blotch is particularly aggressive under high relative air humidity.

Our results suggest that malting barley yield and quality is mainly influenced by weather conditions during the vegetation period and to a lesser extent by fertilisation, fungicide treatment and variety. Our results are in concordance with the findings of Therrien et al. (1994) and Schelling (2003). High protein content in grains is shown to be caused by higher mean temperature and low precipitation during tillering and grain filling periods (Morgan and Riggs, 2006). We confirmed this, as the highest protein content occurred in 2011. The growing conditions during the grain filling period in July 2011 were particularly dry and warm. In contrast, the lowest protein content was found in 2012 when conditions of high precipitation and moderate temperatures were prevailing. According to Rajala et al. (2011), decreased TKW of barley is caused by drought conditions during the grain filling stage, which was also the case in our experiment in 2011. In contrast to TKW, TW was higher in drought conditions of 2011.

Overall, fungicide treatments in our experiment had marginal or moderate positive effect on grain quality parameters. Similarly to previous research by Conry and Dunne (2001) we did not find any clear trend that fungicide application had effect on protein content. Our results indicated that fungicide application somewhat increased TKW, TW and grading, which is in accordance with Jayasena et al. (2002), Turkington et al. (2012), and Bingham et al. (2014). As expected, higher fertilisation application increased grain yield and protein content, however, fertilisation had minor effect on TW, TKW, and grading. Previous research has shown that increasing fertiliser application can significantly improve TW and TKW (Conry and Dunne, 2001; Pettersson and Eckersten, 2007). However, we did not find similar clear effects in our study. Slightly higher levels of TW and TKW were found in the medium fertiliser treatment N2, but not at the highest level N3. It is expected that plants produce generally more tillers and kernels in ears at the higher fertilisation level, which can result in overall smaller kernels. Previous studies (Therrien et al., 1994; Bleidere, 2008) suggested that quality characteristics of barley could be closely connected to variety. In our study, 'Propino' stood out in terms of high TKW and good grading, but had the lowest TW. 'Grace' had high TW, but was sensitive to drought, because TKW and grain yield decreased in conditions of low soil moisture.

Fungicide treatment had no significant effect on grain yield in our trial, which can be explained by low infection severity of barley varieties during the study period. The impact of disease on yield depends largely on the magnitude of the epidemic (Paveley et al., 2001). According to Bingham et al. (2014) and our results, fungicide use in varying environmental conditions does not guarantee increase of the yield, since it depends on many other factors, such as disease severity, plant growing conditions, plant stress conditions, disease resistance of variety etc.

In conclusion, our results showed that barley disease severity, grain yield and quality in the Northern Baltic region depended mostly on weather conditions of the particular year. Higher levels of fertiliser input increased grain yield and protein content but had marginal effect on other quality traits such as TW, TKW, and grading. However, the best quality of malting barley was achieved at the medium fertilisation level. Fungicide treatment had no influence on grain yield and protein content, but slightly improved TKW, TW and grading. We therefore conclude that fungicide treatment is not necessary in the Northern Baltic region in case of low infection intensity of barley by leaf blotch diseases. In addition, the yield potential of tested varieties was similar, but some quality traits, such as TKW, TW and grading depended on variety. 'Propino' stood out in terms of high TKW and good grading. 'Grace' sowed better resistance to net blotch and had high TW, however it was sensitive to drought.

\section{ACKNOWLEDGEMENTS}

This research was the collaboration between ECRI and farmers (Kevili Agricultural Association) and was supported by Rural Development Plan Submeasure 1.7.1 cooperation in the development of new products, processes and technologies in the sectors of agriculture, food and forestry. Our greatest thanks to Inga Hiiesalu for English proofreading.

\section{REFERENCES}

Anonymous (2015). Viking Malt. Discovering the World of Malt. Barley Report. September 2015. Available at:

http://www.vikingmalt.com/wp-content/uploads/2015/09/Malting-Barley -Report-September-2015.pdf (accessed 10 November 2015).

Bingham, I. J., Young, C. S., Bounds, P., Paveley, N. D. (2014). How do fungicides increase yield of spring barley when disease is low or absent? In: Proceedings Crop Protection in Northern Britain, in February 2014, Dundee, Scotland. Bage Bros Ltd, pp. 77-82.

Bleidere, M. (2008). Genetic and environmental effect on the grain quality of spring barley. Latvian J. Agron., 11, 33-39.

Bleidere, M., Mežaka, I., Legzdiņa, L., Grunte, I., Beinaroviča, I., Rostoks, N. (2012). Variation of spring barley agronomic traits significant for adaption to climate change in Latvian breeding programmes. Proc. Latvian Acad. Sci., Section B, 66 (1/2), 30-35. 
Briggs, D. E. (1998). Malts and Malting. Blackie \& Professional, London. 796 pp.

Conry, M. J., Dunne, B. (2001). Influence of number and timing on fungicide applications on the yield and quality of early and later-sown spring malting barley grown in the south-east of Ireland. J. Agric. Sci., 136, 159-167.

Cook, R. J., Hims, M. J., Vaughan, T. B. (1999). Effects of fungicide spray timing on winter wheat disease control. Plant Path., 48, 33-50.

Cooper, J. M., Schmidt, C. S., Lueck, L., Shotton, P. N., Turnbull, C., Leifert, C. (2007). Effect of organic, low-input and conventional production systems on yield and diseases in winter barley. In: Niggli, U., Leifert, C., Alföldi, T., Lück, L., Willer, H. (eds.). Improving Sustainability in Organic and Low Input Food Production Systems. Proceedings of the 3rd International Congress of the European Integrated project Quality Low Input Food (QLIF), 20-23 March 2007, Hohenheim, Germany, pp. 235-238. Available at:

https://www.fibl.org/fileadmin/documents/shop/1455-organic-foodproduction.pdf (accessed 20 July 2015)

Deacon, J. W. (2006). Fungi as plant pathogens. In: Fungal Biology. 4th ed. University of Edinburg, Blackwell Publishing, UK, pp. 213-279.

Duveiller, E., Altamirano, G. (2000). Pathogenicity of Bipolaris sorokiniana isolates from wheat roots, leaves and grains in Mexico. Plant Path., 19, 235-242.

Grissom, R. J., Kim, J. J. (2012). Effect Sizes for Research: Univariate and Multivariate Applications. $2^{\text {nd }}$ ed. Taylor \& Francis Group, New York. 429 pp.

Jalli, M., Laitinen, P., Latvala, S. (2011). The emergence of cereal fungal diseases and the incidence of leaf spot diseases in Finland. Agric. Food Sci., 20, 62-73.

Jayasena, K. W., Loughman, R., Majewski, J. (2002). Evaluation of fungicides in control of spot-type net blotchon barley. Crop Prot., 21, 63-69.

Khan, T. N. (1987). Relationship between net blotch (Drechslera teres) and losses in grain yield of barley in Western Australia. Austr. J. Agric. Res., 38, 671-679.

Leistrumaite, A., Paplauskiene, V., Masauskiene, A., Statkeviciute, G. (2008). Investigation and utilization of spring barley germplasm for breeding programs. In: Proceedings of the $10^{\text {th }}$ International Barley Genetics Symposium, in April 2008, Alexandria, Egypt. Aleppo, Syria, pp. 68-78.

Meier, U. (Ed.) (2001). Growth Stages of Mono- and Dicotyledonous Plants. BBCH Monograph 2. Federal Biological Research Centre for Agriculture and Forestry, pp. 14-16.

Morgan, A. G., Riggs, T. J. (2006). Effects of drought on yield and grain and malt characters in spring barley. J. Sci. Food Agric., 32, 339-346.

O’Donovan, J. T., Turkington, T. K., Edney, M. J., Clayton, G. W., McKenzie, R. H., Juskiw, P. E., Lafond, G. P., Grant, C. H., Brandt, S., Harker, K. N., Johnson, E. N., May, W. E. (2011). Seeding rate, nitrogen rate, and cultivar effects on malting barley production. Agr. J., 103, 709-716.

Olesen, J. E., Jorgensen, L. N., Petersen, J., Mortensen, J. V. (2003). Effects of rate and timing of nitrogen fertiliser on disease control by fungicides in winter wheat. Grain yield and foliar disease control. J. Agric. Sci., 140, $1-13$.

Received 25 October 2016

Accepted in the final form 18 December 2016
Olesen, J. E., Trnka, M., Kersebaum, K. C., Skjelvåg, A. O., Seguin, B., Peltonen-Sainio, P., Rossi, F., Kozyra, J., Micale, F. (2011). Impacts and adaptation of European crop production systems to climate change. Europ. J. Agron., 34, 96-112.

Oscarsson, M., Andersson, R., Åman, P., Olofsson, S., Jonsson, A. (1998). Effect of cultivar, nitrogen fertilisation rate and environment on yield and grain quality of barley. J. Sci. Food Agric., 78, 359-366.

Paveley, N. D., Sylvester-Bradley, R., Scott, R. K., Craigon, J., Day, W. (2001). Steps in the prediction of the relationship of yield on fungicide dose. Phytopathology, 91 (7), 708-716.

Pettersson, C. G., Eckersten, H. (2007). Prediction of grain protein in spring malting barley grown in northern Europe. Eur. J. Agron., 27, 205-214.

Rajala, A., Hakala, K., Mäkelä, P., Peltonen-Sainio, P. (2011). Drought effect on grain number and grain weight at spike and spikelet level in six-row spring barley. J. Agron. Crop Sci., 197, 103-112.

Savin, R., Molina-Cano, J. L. (2002). Changes in malting quality and its determinants in response to abiotic stresses. In: Slafer, G. A., Molina-Cano, J. L., Savin, R., Araus, J. L., Romagosa, I. (eds.). Barley Science: Recent Advances from Molecular Biology to Agronomy of Yield and Quality. Food Products Press, USA, pp. 523-550.

Schelling, K., Born, K., Weissteiner, C., Kühbauch, W. (2003). Relationships between yield and quality parameters of malting barley (Hordeum vulgare L.) and phenological and meteorological data. J. Agron. Crop Sci., 189, 113-122.

Sooväli, P., Koppel, M. (2010). Efficacy of fungicide tebuconazole in barley varieties with different resistance level. Agric. Food Sci., 19, 34-42.

Spaner, D., Todd, A. G., McKenzie, D. B. (2001). The effect of seeding rate and nitrogen fertilisation on barley yield and yield components in cool maritime climate. J. Agron. Crop Sci., 187, 105-110.

Schwarz, P. B., Horsley, R. D. (1996). A comparison of North American two-row and six-row malting barley. Brewing Technol., 4, 48-55.

Therrien, M. C., Grant, C. A., Carmichael, C. A., Noll, J. S. (1994). Effect of fertiliser management, genotype, and environmental factors on some malting quality characteristics in barley. Can. J. Plant Sci., 74, 545-547.

Turkington, T. K., Clayton, G. W., Harker, K. N., Kutcher, H. R., O’Donovan, J. T., Johnston, A. M., Xi, K., Stevenson, F. C. (2004). Impact of seedbed utilization and fungicide application on severity of net blotch (Pyrenophora teres) and production of barley. Can. J. Plant Path., 26, 533-547.

Turkington, T. K., Tekauz, A., Xi, K., Kutcher, H. R. (2011). Foliar diseases of barley: Don't rely on a single strategy from the disease management toolbox. Prairie Soils Crop J., 4, 142-150. Available at: http://www.prairiesoilsandcrops.ca/ (accessed 10 June 2015).

Turkington, T. K., O’Donovan, J. T., Edney, M. J., Juskiw, P. E., McKenzie, R. H., Harker, K. N., Clayton, G. W., Xi, K., Lafond, G. P., Irvine, R. B., Brandt, S., Johnson, E. N., May, W. E., Smith, E. (2012). Effect of crop residue, nitrogen rate and fungicide application on malting barley productivity, quality and foliar disease severity. Can. J. Plant Sci., 92, 577-588.

Vanova, M., Palik, S., Hajslova , J., Buresova, I. (2006). Grain quality and yield of spring barley in field trials under variable growing conditions. Plant Soil Environ., 52, 211-219.

Yang, J. P., Sieling, K., Hanus, H. (2000). Effect of fungicide on grain yield of barley grown in different cropping systems. J. Agron. Crop Sci., 185, $153-162$.

\section{ALUS MIEŽU SLIMĪBAS, RAŽA UN KVALITĀTE — REAKCIJA UZ DAŽĀDIEM LAUKSAIMNIECĪBAS REŽĪMIEM}

Trīs gadu laikā tika noteikta alus miežu slimību attīstība, raža un kvalitātes īpašības pie dažādām mēslojumu un fungicīdu koncentrācijām. Attiecīgā gada laika apstākḷi būtiski ietekmēja visus trīs minētos rādīiājus. Augstākā graudu raža un proteīnu saturs iegūts pie maksimālām minerālmēslojuma devām, tomēr labākā graudu kvalitāte bija pie vidējā mēslojuma līmeņa. Fungicīdu izmantošana neietekmēja graudu ražu un proteīnu saturu, tāpēc secināts, ka Ziemeḷbaltijas reǵionā pie zemas miežu lapu plankumainības intensitātes fungicīdu lietošana nav nepieciešama. 